\title{
Assessment of Consumer Influencing Factor in Decision Making for Selecting Cement Brands
}

\author{
Anjay Kumar Mishra ${ }^{1 *}$, Bishal Sharestha ${ }^{2}$ \\ ${ }^{1}$ Associate Professor, Madan Bhandari Memorial Academy Nepal and Pokhara University \\ 2Managing Director, Balkot Nirman Sewa Private Limited \\ ${ }^{*}$ Corresponding Author \\ Dr. Anjay Kumar Mishra
}

\section{Article History}

Received: 24.09.2019

Accepted: 06.10.2019

Published: 12.10 .2019

\begin{abstract}
Cement is the major construction material used in the civil engineering works due to which its demand is very significant, while it becomes a tough task to select a proper cement brand. The study is focused to assess factors influencing selection of cement brand. The study is conducted at Madhyapur Thimi Municipality among different level of consumer i.e house owner, supplier, contractor/mason and consultant/engineer. Out of 871 permitted under construction building of fiscal year 2016/17, 89 end consumers and 30 suppliers were selected for quesionniare survey. Key informat interview was conducted for in depth information while focus group discusiion were done to assess the determinance of consumer behaviour and brand. Hypothesis test were done to find the significance of advertisement, consultant/engineer, mason/contractor, friends/relatives and supplier/retailer. The study reveals that $70 \%, 26.67 \%$ and $3.33 \%$ of total consumers considered quality, brand image and years of establishment respectively as the main factor while selecting cement brands. Hetauda, Udayapur, Shivam, Maruti and Argakhanchi cement was found to be consumed by $50 \%, 23.34 \%, 20 \%, 3.33 \%$ and $3.33 \%$ respectively. Based on Hypothesis test, consultant and friend/relatives have a significant role in the purchasing decision of cement.
\end{abstract}

Keywords: Year of establishment, quality, price and brand image.

\section{INTRODUCTION}

Cement is most important material for construction Manufacturing. Infrastructure being the major indicator of development and the R.C.C structurers being the most common, popular, easy and durable method of construction, demand of cement is increasing every year. Mostly, cement is used as a mortar in masonry, precast pipes and elements, pointing and plastering works and for different type of concreting the structural elements. It is manufactured through a closely controlled chemical combination of calcium, silicon, aluminum, iron and other ingredients in the required temperature. Chemical composition between the ingredients, their sufficiency and the temperature during its manufacturing process highly influences its consistency of strength development. Thus, the manufacturing process of different cements such as Ordinary Portland Cement (OPC), Pozzalana Portland Cement (PPC) and Portland Slag Cement (PSC) differs from each other as per their property related with their strengths. Based on the property of cement, they are used for different purpose in different places considering the climatic factors that affects the quality of cement. To confirm the quality standards of the cement, different types of tests are conducted in the laboratories of the cement industries that actually show their physical and chemical properties for which it can best used depending upon the requirements.

It is used almost in every construction. Although Nepal is not developed country and lots of development activities are going on and the demand of cement is growing day by day for buildings, bridge, and road or hydropower project. Nepalese cement industries are continuously thriving to meet the demand of cement [1]. The Number of brands in cement industry is growing and with increase in number of brands, it is essential to understand how the consumers are attracted to the respective cement brands [2]. To succeed a Manufacturing or organization the product should be liked by the people. Till in Nepal company conform OPC 33 Grade only though 53 grade cement is cost effective in terms of quality, content and rate assessment[3] it was further argued that grading of Ordinary Portland Cement should be done. Even it was asked by Mishra and Chaudhary [4] that Inspection of cement in terms of quality should be done so that cement manufacturers could be compelled to maintain their quality.

Copyright @ 2019: This is an open-access article distributed under the terms of the Creative Commons Attribution license which permits unrestricted use, distribution, and reproduction in any medium for non commercial use (NonCommercial, or CC-BY-NC) provided the original author and source are credited. 


\section{ObJectives OF THE Study}

The overall objective of this study is to identify the consumer influencing factor in decision making to select the cement

brands.

\section{LITERATURE REVIEW \\ Consumer Decision Making Models}

Engel et al. [5] point out that environmental influences may affect the decision sequence acting on the consumer's motivation and intention, and that unpredictable factors (such as non-availability of the desired brand or insufficient funds) may result in modification of the actual choice made by a consumer. This model assumes that observed consumer behaviour is preceded by intrapersonal psychological states and events (attitude intention- purchase sequence). Moreover, the model depicts these psychological events as outputs of the processing of information, taking for granted that consumers seek and use information as part of their rational problem solving and decision making processes.

\section{The Personality Perspective}

As noted above, some purchases have more personal relevance than others. While this partly reflects on factors such as price, it also bears on the way in which some products enhance the consumer's self-concept i.e., possessions are considered to reflect on a consumer's image of him or herself. The dramaturgical perspective on consumer behaviour views people much like actors who play different roles [6]. Goffman [6] introduced the concept a 'managed situation', the idea that people manage the impression that others have of them by the way they present themselves. In the presence of others, the actor is seen to organize his activity in order to express an impression that he wishes to convey. The object of the study of role theory is to increase understanding of role enactment of individuals in social settings, so as to understand and predict behaviour. Marketing interest in the study of personality derives from the possibility that, in spite their uniqueness as individuals, members of groups and aggregates may possess a given trait or type in common with each other e.g., extraversion; such groupings (typologies) might then become the basis of separate market segments and justify special marketing action[7].

Personality in general is understood as a concept which accounts for the apparent consistencies and regularities of behaviour over time and across a variety of situations [8]. As such, personality constructs explain those aspects of behaviour which are relatively stable across situations and, as a result, are predictive of future behaviour. Personality has also been understood as the unique way in which traits, attitudes, aptitudes, etc. are organized in an individual [9] and this draws attention to the ways in which individuals differ from one another through the peculiar configuration of traits and other characteristics each possesses. While individuals might not always be uniform and predictable in their patterns of choice in different situations, it might be possible to make sense of and to forecast the general reactions of broadly- defined groups and classes of purchasers. As discussed next, it is this concept of consumer general behavioural response patterns that forms the basis for marketing's personality based segmentation strategies.

\section{The Motivational Perspective and Psychographics}

The possibility of using measures of personality to guide marketing action, for example in segmenting markets psychographically, tailoring new brands to the susceptibilities of innovative consumers, and repositioning mature brands, has encouraged a large volume of research. Few significant relationships, which would be of interest to marketing managers resulted from the research which concentrated upon the search for links between aspects of consumer choice (such as brand selection) and highly specific personality traits (such as sociability). However, the investigation of personality types, broad bundles of complementary traits which describe an individual's general pattern of behavioural response has shown more promise in the quest to describe and predict consumer behaviour. Thus, the success of personality research is also partly attributed to the simultaneous widespread dissatisfaction with psychoanalytical techniques of motivational research. The first attempts to apply Fruedian and neo-Feudian (e.g., Horney and Adler) concepts, were made in the 1950s, when a perspective known as motivational research was developed. Ernest Ditcher advocated the use of psychoanalytical techniques to uncover hidden motivations (e.g., to understand the deeper meanings of products and advertisements). He strongly argued that people could not be asked why they did what they did directly, because most of the time they did not know. Ditcher's ideology of "truth-is-in-the-subconscious", behind his in-depth interviews was muchcriticized by traditional statistical researchers who called such motivational research a "pseudo-science". Perhaps the most persistent problem with motivational research was that it failed one of the cardinal rules of scientific methods - replicability. Two researchers could draw two totally different conclusions from the same interview, because motivational research was so dependent upon individual interpretation. Thus, the widespread dissatisfaction with simple demographics and disenchantment with motivational research, coupled with the increasing accessibility of computers gave many researchers the raw material needed to measure the quantitative elements of personality traits, motivations, and psychological attributes [10].

\section{The Attitudinal Perspective}

Attitudes are predispositions felt by buyers before they enter the buying process. The buying process itself is a learning experience and can lead to a change in attitudes [11]. Thus, attitudes do not automatically guarantee all types of behaviour. They are really the product of social forces interacting with the individual's unique temperament and abilities. Thus, as discussed above, social 
influences determine some but not all of the behavioural variations in people. Two individuals subject to the same influences are not likely to have identical attitudes, although these attitudes will probably converge at more points than those of two strangers selected at random. Most researchers agree that an attitude has three components: affect, behaviour, and cognition. Affect refers to the way a consumer feels about an attitude object, behaviour involves the person's intentions to do something with regard to an attitude object, and finally, cognition refers to the beliefs a consumer has about an attitude object. While all three components of an attitude are important, their relative importance will vary depending upon the consumer's level of motivation with regard to the attitude object. Attitude researchers have developed the concept of a hierarchy of effects to explain the relative impact of the three components. Each hierarchy specifies that a fixed sequence of steps occur en route to an attitude [12].

According to the theory of cognitive information processing, attitudes are formed in the order of beliefs, affect, and behaviour. Attitudes based on behavioural learning follow the beliefs, behaviour, and affect sequence. And finally, attitudes formed based on the experiential hierarchy follow the affect, behaviour, and beliefs route. A consumer who is highly involved with a product category and who perceives a high level of product differentiation between alternatives will follow the cognitive hierarchy (beliefsaffect-behaviour). From the marketer's perspective, the sequence of attitude formation is pertinent from a communications point of view. Accordingly, here, a marketer will first attempt to create Attention, then Interest and Desire, and finally Action (AIDA). Thus, from a strategic point of view, Multi-attribute attitude models, such as the Fishbein [13] model, have proved useful in specifying the different elements that work together to influence people"s evaluations of attitude objects and ultimately predict consumer attitudes; products or services may be composed of many attributes, or qualities, some of which may be more important than others to particular people. Also, a person's decision to act on his or her attitude is affected by other factors, such as whether it is felt that buying a product would be met with approval by friends and family. The complexity of attitudes is underscored by multi- attribute attitude models, in which sets of beliefs and evaluations are identified and combined to predict an overall attitude [14].

\section{The Situational Influence Perspective}

A situation is defined by factors over and above the characteristics of a person and product. For example, as explained below, situational effects may be behavioural (e.g., entertaining friends), experiential, or perceptual (e.g., being depressed or being pressed for time) [15]. According to the behavioural influence perspective of low involvement decision situations, consumer decision making is a learned response to environmental cues, as when a person decides to buy something on impulse that is prompted as a "surprise special" in a store. According to this approach, then marketers must concentrate on assessing the characteristics of the environment, such as the physical surroundings and product placement that influence members of that target market. For example, points of purchase stimuli (such as product samples) are particularly useful in inducing impulse purchases. The experiential perspective stresses the gestalt, or totality, of the product or service. Consumers may be highly involved in a decision, but may not lend themselves to the rational approach. Marketers focus on measuring consumers' affective responses to products or services and develop offerings that elicit appropriate subjective reactions and employ effective symbolism. Situational effects can also be perceptual. For example, stress can impair information processing and problem solving abilities. In addition, time poverty can impact buying decisions. An individual's priorities determine his or her timestyle [16].

\section{The Positivist Perspective}

The traditional positivist approach is established on the premise that consumers are largely rational, stable, and knowable entities. The positivist philosophical stance is characterized by an emphasis on scientific observation and testing. The objective of this type of research is therefore, to observe empirical facts and to establish generalizable laws that can use to predict and control behaviour. The outcome of the positivist pursuit is directed toward advancing the overall goals of marketing practice. The positivist perspective therefore assumes that a single reality exists; events in the world can be objectively measured; and the causes of behaviour can be identified, manipulated, and predicted. Thus, the basis of the traditional perspectives is that consumer behavior is controlled by forces which operate largely beyond the control of consumers themselves [17].

Change is not something which consumers do for themselves, rather it is a result of something that is done to them by some internal (e.g., trait) or external (environmental) force over which they have little or no control [18]. As Firat et al. [19], observe "Consumer behavior theories believe in consistency and orderliness of consumer behaviour. Thus, the general assumption has been that if and when informed about such characteristics of the consumer [cognitive responses, conditioned responses, personality traits etc.], some meaningful prediction of their actions can be achieved".

The traditional perspectives therefore, assume a highly "reactive" or passive consumer. For instance, the behavioural perspective assumes that consumers lack a conscious self-reflective ability and as a result can be totally controlled and manipulated by marketers through environmental engineering [20]. Finally, the adoption of the traditional-positivist approach, the dominant paradigm in consumer research, has proved quintessential to the creation of applied consumer knowledge and accordingly the evolution of marketing practice. The more recent non-positivist perspectives, however, aim to redress some of the criticisms of the traditional approaches, as discussed next.

\section{The Non-Positivist Perspectives}

In contrast to the traditional perspectives, the interpretive and postmodern perspectives of consumer behaviour attribute 
consumers with the capacity to "proactively" assign meaning to and represent their environments rather than just passively respond to them the interpretive perspective for example suggests, that behaviour is channeled by the content and structure of consumer's subjective meaning systems [12].

The non-positivistic perspectives (particularly postmodernism) question and criticize modernism's claims on philosophical, cultural, and empirical grounds. Firat et al. [19] argue that, "modernism reduces the world into simple dichotomous categories of consumer/producer, male/female and so on. Postmodernism (as does interpretivism) regards these dichotomies as unsuccessful historical attempts to legitimize partial truths." In sum, it can be argued that the new perspectives may legitimately be classified as part of the non-positivist movement, which acknowledges the social, complex, and often irrational and unpredictable nature of consumer behaviour. This view focuses on not just the process of buying, but gives equal significance to the experiential and meaningful aspects, which under pin consumption.

\section{Factors Influencing Consumer Perceptions of a Brand}

Kotler [21] defined perception as the process by which information is received, selected, organised and interpreted by an individual. Some of the factors that influence consumer perceptions of a brand include:

- Quality: This is one of the factors which consumers take into account when making their choice of brand. According to Uggla [20], quality is an integrals part of brand identity.

- Price: McDonald and Sharp [23] stated that price can be used as a reason for brand choice in two ways; either by going for the lowest price in order to escape financial risk or the highest price in order to achieve product quality.

- Influence by others: According to Kotler et al. [24], influence by others plays a vital role in consumer's decision processes. Consumers have the habit of consulting each other regarding a new product or brand and seeking their advice. The advices of other people have a strong effect on consumers buying behaviour. However, the degree of such effect depends on the situation or individual. Later adapters tend to be more influenced than early adapters. Influence by others cannot be sharpened by marketers. A buyer can also be influence culturally i.e. value, behaviour and preferences from family or other institution or socially i.e. by a small group like family or membership group. Purchase decision could also be influenced by attitude of others. For example, a consumer wants to buy MacLean, while in the shop he or she comes in contact with a friend who says Colgate makes my teeth brighter and whiter. The consumer can be forced to buy Colgate.

- Advertising: The main aim of advertisement is to create awareness. Advertisement is a conspicuous form of communication. According to Aaker [25], if advertising, promotion and packaging embrace a regular positioning strategy over a period of time, there is the tendency that the brand will be strong. Some ways of reaching and communication to consumers through advertising is through television, cinema, radio, bill board etc.

- Packaging: This is the process of designing the cover of a brand/product.

According to Kotler et al. [26], packaging is a form of advertisement in the sense that it sales duties such as attracting consumers, describing and selling the product.

- Convenience: According to Lin and Chang [27], convenience of a brand has a significant effect on consumer. In other word, easy access to brand/product in store is vital when buying low involvement product.

\section{Branding and Customer Acceptability}

Kotler et al. [28] defined a brand as "a name, term, sign, symbol, design or a combination of these that identifies the makers or seller of the product or services". This definition is based on the use of a brand name, symbols and signs to distinguish a product from its competitor. According to Keller [29], the American market association (AMA) defines a brand as a "name, term, sign, symbol or design or a combination of them, intended to identify the goods and services of one seller or group of sellers and to differentiate them from those of competitor".

A brand is different from a product. According to Kotler [3], a product is anything which can be presented to a market for purchase, use or consumption that is possible of satisfying need or want. He went further to say that a product is made up of goods that have physical appearance, service, events, experiences, places, persons, organisation, properties, information and ideas. According to De Chernatony and MacDonald [23], a brand goes beyond physical constituents and what it stands for, it has some additional attributes which although maybe intangible but are still important to consumers' consideration. A brand has added value which differentiate it from a product [31]

Jones and Slater [32] sum up these added values as those that develop from experiences of the brand; those that arise as a result of usage of the brand, which could be as a result of consumers' association with the brand; those that arise from an assumption that the brand is powerful; and those that arise from the appearance of the brand i.e. packaging the product. According to Doyle [31], these added values play a vital role in many consumers buying decisions, as brands are purchased from emotional motivation as well as functional motivation.

Many researchers have adopted this added value concept into their brand definition. For example, De Chernatony and 
MacDonald [33] established the following definition: "In identifiable product; service, person or place augmented in such a way that the buyer or user perceives relevant, unique added value which match their needs most closely. Furthermore, its success results from being able to sustain these added values in the face of competition".

One of the functions of a brand is that it serves as an identifier of product and services so that it can be differentiated from other products and services of the same class. Aaker [25] said that brand knowledge serves as a protector for both the manufacturer and consumer. Schmitt [34] said that a brand should not just be an identifier, he went further to say that a good image and name is insufficient; delivered experience is also important. Schmitt [34] recommended two ways to branding:

- The brand has to be viewed as an identifier where the logo, slogan, names forms a particular image and awareness for the consumer.

- The brand has to be viewed as an experience provider where the logo, slogan, names, event and contacts by consumer provides consumers affective, sensory, lifestyle and create relation with the brand.

Kotler and Armstrong [35] also see brand to be beyond an identifier. It represents consumer's sensitivity and emotional attachment to the product. According to Feldwick [36], a brand is a distinguishable symbol of origin and an assurance of performance.

Conclusively, a brand can be said to be a symbol of all facts associated with a product and service. A brand commonly includes a logo, a name and any other visible elements such as symbols and images. It also consists of other sets of expectations related to a product or service which normally arise in people's mind.

\section{Brand Awareness}

Brand awareness can be referred to as the degree of consumers' familiarity with a brand. Aaker [25] and Keller [37] stated that brand awareness is a vital element of brand equity. According to Rossiter and Percy [38], brand awareness is the ability of consumers to distinguish a brand amongst another brand. Keller [37] conceptualized brand awareness as comprising of brand recall and brand recognition. He went further to say that brand recall is the ability of consumers to remember a brand from their mind when the product class is made know.

Keller [37] argued that "brand recognition may be more important to the extent that product decisions are made in the store". Rossiter et al. [39] noted that brand attitude and intention to purchase a product can only be developed through brand awareness. According to Aaker [25], there are three levels of brand awareness:

- Brand recognition: It is the ability of consumers to identify a certain brand amongst other i.e. "aided recall". Aided recall is a situation whereby a person is asked to identify a recognized brand name from a list of brands from the same product class.

- Brand recall: This is a situation whereby a consumer is expected to name a brand in a product class. It is also referred to as "unaided recall" as they are not given any clue from the product class.

- Top of mind: This is referred to as the first brand that a consumer can recall amongst a given class of product.

Many researchers have seen brand awareness as an element that plays a vital role in consumer's choice of brand. In Lin and Chang [27], the result of their study established that brand awareness had the most powerful influence on consumers purchase decision.

Hoye and brown [40] as cited by Lin and Chang [27] their study examined the importance of brand awareness in consumers' decision making process and they found out that brand awareness was a primary factor. Also, Jiang [41] found out in his study that brand recognition influences consumer's choice. Hence, in our present study, brand awareness is conceptualized as consisting of brand recognition and top of mind.

\section{Achieving Brand Awareness}

Aaker [25] prescribed some of the following factors as ways to achieve brand awareness: Involve a slogan or jingle: a slogan is a visible feature of a brand. There can be a strong link between a slogan and a brand. The slogan and jingle are powerful and can be a great change for a brand. Be different and memorable: as a result of the similarity between product and their means of communication, product differentiation is important.

- Symbol exposure: a known symbol will make it easier to recall and memorize a visible illustration of the brand. A logo that is connected to an existing brand or a developed brand will play a vital role in developing and keeping brand awareness.

- Publicity: one of the most important ways to get publicity and create awareness is through advertisement.

- Event sponsorship: sponsorship of event can also help to create and maintain awareness.

- Consider brand extension: one way to increase brand recall is to show the logo or name on the product and make the name popular. Example of this is coca-cola which is more publicized than the key product.

- Using cue: packaging is one of the most significant cues to a brand due to the fact that it is what the purchaser sees when purchasing a product. If the product or brand is not known, the only means of contact to the brand or product is the package. 


\section{Brand Image}

Engel Blackwell and Miniard [5] referred to brand image as the combined effect of brand association or consumers' perception of the "brands tangible and intangible association". Keller [37] see brand image as a perception or association consumers form as a result of their memory concerning a product. According to Low and Lamb [42], brand image can also be referred to as the emotional perception or reason that consumers place to a particular brand. Thus, brand image does not exist in the features, technology or the actual product itself, it is sometimes brought out by advertisement, promotion or users. Brand image enables a consumer to recognize a product, lower purchase risks, evaluate the quality and obtain certain experience and satisfaction out of product differentiation.

Marketing researchers such as Keller [37] have proposed that brand image is an important element of brand equity. Krishnan [43] found out that brands with high brand equity are prone to more positive brand associations than those with low brand equity. Also, Lassar et al. [44] found out that brand with high brand image rating always have higher brand equity and premium price. Conclusively, Kwon [45] reported that positive brand image is mostly likely associated with preferred brands.

Researchers have proposed that brand equity is to an extent driven by the brand association composition of the image. According to Keller [37], favorable, unique and strong associations are assumed to provide a positive brand image which will create a bias in the mind of consumers thereby increasing the brand equity. Pitta and Katsanis [46] also stated that a unique, favorable and strong brand image allows the brand to be easily differentiated and positioned in the consumers' mind, thereby adding to the possibility of increased brand equity.

Conclusively, brand image can be said to be the brand association or consumer's perception about a particular brand as a result of their association with the brand.

\section{Perceived Quality}

According to Aaker [25] and Keller [37], perceived quality is a core dimension of customers based brand equity as it relates to the willingness to pay a price premium, brand choice and brand purchase intention.

Low and Lamb Jr [42] referred to perceived quality as the perception of the superiority of a brand when compared to alternative brand. Zeithamal [47] defined perceived quality as consumer's judgment about the whole product superiority or excellence. According to Szymanski and Henard [48], one of the antecedents of satisfaction is perceived quality. Like brand association, perceived quality provides consumers with value and give them reason to differentiate a brand from another.

Justified by Researchers such as Carman [49], Parasuraman et al. [50], perceived quality can be said to have a positive effect on customers purchase intention. Although there are inconsistencies on the available empirical evidence for example, Boulding et al. [51] considered service quality as one of the factors leading to purchase intention. In Cronin and Taylor [52] as cited by Juan Carlos et al. [53] direct effect was not significant whereas there was an indirect effect which rose from satisfaction. Taylor and Baker [54] speculated that perceived quality liked with satisfaction has an effect on consumers purchase intention.

Therefore, perceived quality can be said to be consumer's perception of the superiority of a brand which enables them to differentiate a brand from another.

\section{Brand Loyalty}

According to Aaker [25], brand loyalty is "the attachment that a customer has to a brand". Yoo and Donthun [48] also referred to brand loyalty as the tendency to be loyal to a brand and this can be shown by the intention of the consumer to buy the brand as a foremost choice.

Oliver [55] also defined brand loyalty as "deeply held commitment to re-buy or re-patronize a preferred product/service consistently in the future, thereby causing repetition of same-brand or same brand set purchasing, despite situational influence and marketing efforts having the potential to cause switching behaviors".

Odin et al. [56] stated that brand loyalty can either be behavioral or attitudinal. Behavioral loyalty comprises of repeated purchases of the brand. According to Dekimpe et al. [57], one advantage of this is that it measures observable behaviours rather than self-reported deposition or intention. It is easier and cheaper to measure.

According to Chaudhuri and Holbrooks [58], attitudinal loyalty can be referred to as the extent of dispositional promises with respect to some particular advantages connected with the brand while behavioral loyalty has to do with the intention torepeat a purchase. Although, the definition of behavioral brand loyalty deals with consumer's sincere loyalty to a brand as shown in purchase choice, the definition based on attitudinal perspective stresses on consumers' intention to be loyal to the brand. It is presumed that consumers understanding of quality will be associated with their brand loyalty. As the more loyal a consumer to a brand, the more 
he/she is presumed to see the brand as a superior quality and vice versa. Also, the more favorable association's consumers have towards a brand, the more their loyalty and vice versa.

\section{Aaker [25] classified loyalty as follows:}

- $\quad$ Non- customer: these are people who buy the brands of competitors.

- Price switcher: these are the once that are sensitive to price.

- Passive loyal: these once are purchase brand/product as a result of habit rather than reason.

- Fence sitters: are those that are indifferent between several brands.

- Committed: are those who are honestly loyal to the brand.

Kotler also classified loyalty to include switchers, soft-core, hard-core loyal and shifting loyal. So far, we have been able to connect the views of various researchers that address the issue of consumer based-brand equity. From our readings and what we have been able to gather, we will like to state here that consumers base brand equity has influence on consumers' perception of brand. Favorable perceptions of quality are more presumed to be developed by consumers who hold a favorable association toward a brand.

Furthermore, consumers brand awareness is presumed to be high when they have strong association and perceived quality of the brand and vice versa. Thus, consumer's perceptions about the quality of a brand are presumed to be high when they have strong association with the brand and vice versa.

\section{Benefits of a Good Brand}

According to Dolak [59], a strong brand will create the following benefits amongst others:

- Build name recognition for your product/company.

- Influence the consumer's buying decision.

- Build trust and emotional attachment to a firm's product/service.

- Make purchase decision easier. For example, in a commodity market where product and services are indistinguishable, it will enable customers trust and create a set of beliefs about your product even without knowing the uniqueness of your products and characteristics.

A strong brand increases the consumer's attitude towards a particular brand's product and services and the strength of such attitude is developed through experience with such brand.

Consumers experience help to increased perceived qualities, inferred attributes and eventually leads to brand loyalty which are not easy to evaluate except before purchase.

A strong brand enjoy benefit such as reduced competitive advantage, premium price greater customer loyalty, profitability, reduce the perceived risk of consumers who are not so sure of their decision.

\section{Methodology}

\section{Study Area}

The study area of the research was Madhyapur Thimi Municipality which is located in Bhaktapur district. After the major earthquake of April, 2015, reconstruction works and new construction of buildings is significantly increased in the area due to migration of pouplation from major earthqauke affected districts. In the fiscal year 2016/17, there were 871 newly registered building for the construction of new building which was involved in this study. 


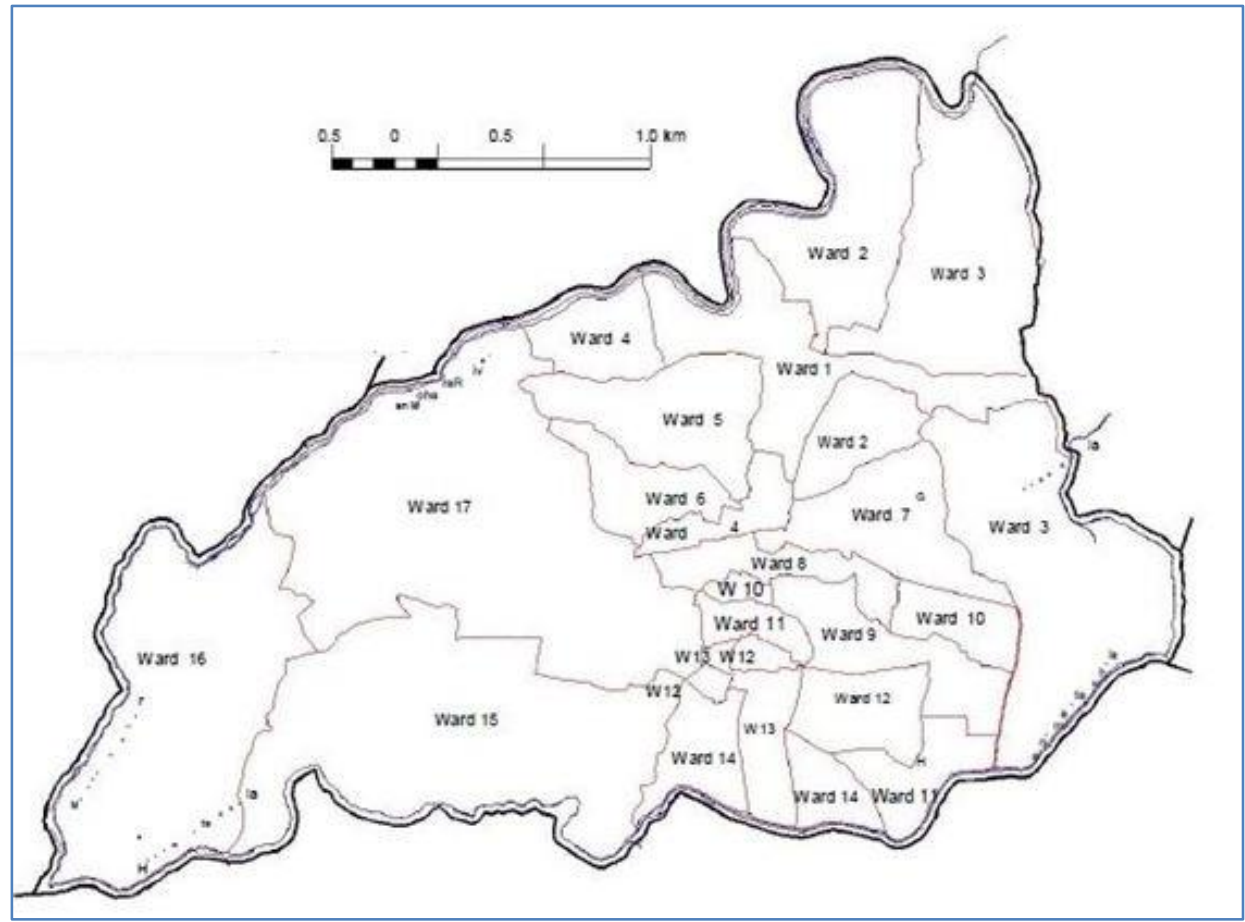

Fig-Error! No text of specified style in document..1: Map of Madhyapur Thimi Muncipality [60]

\section{ReseARCH APPROACH}

Both qualitative and quantitative analysis was done to get in depth knowledge about the consumer perception towards the cement brand and marketing strategy followed by the cement industries. Qualitative analysis helped to know about the consumers' influencing characteristics through focus group discussion and key informant interview done with Masons, Contractors, Engineers and Architects. Similarly, the study adopted the survey methods by using the quantitative methods of data collection and statistical analysis. This method described customer's perception and acceptability of different brands of cement. This design was selected because it has the advantage of describing people attitude and perception towards different brands of cement. It also provides meaningful explanations on people perception. Similarly, for the lab test, standard codes were followed and are compared with the test results.

\section{Sample Size}

The total number of registered building for the construction in the fiscal year 2016/17 was 871 .

Thus, the sample size is calculated using the formula as below:

$$
n=N /\left(1+N^{*}\left(e^{\wedge} 2\right)\right) \quad[61]
$$

where, $n=$ Sample size

$\mathrm{N}=$ Population

$\mathrm{e}=$ Marginal error

Taking $e=0.1$, Sample size is calculated which is 89 .

Therefore, the sample size for the data collection of the consumer was taken as 89 .

For the sample size of supplier, central limit theorem was used and taken as 30 for the data collection.

\section{Method of data Collection \\ Primary Data \\ Key Informant Interview}

Key Informant Interview was done with Engineers and Architects in Madhyapur Thimi who were involved in the field of building constructions. Through snowball sampling method total number of 5 Architects and Engineers were identified for the interview. They were asked individually about the current market status of the cement brand and the purchasing behaviour of the consumers of different cement brands. Also, the importance of the promotional tools and the advertisement were discussed during the interview. 


\section{Questionnaire Survey}

Questionniare survey was done with the suppliers and consumers to collect the data involving marketing strategies of cement industries and the consumer behaviour in decision making to purchase the cement brands. Out of 871 consumers registered for the Building Permit in the Fiscal Year 2016/17, questionnaire survey was conducted with 89 sample population of consumer and 30 suppliers registered in Madhyapur Thimi Municipality. Multiple choice questions and likert five scale point question were prepared separately for both suppliers and consumers. It helped to analyze the consumer behaviour from two perspective; one from consumer itself and another from the supplier with cross verifciation of the results.

\section{Focus Group Discussion}

Focus group discussion was done with mason and contractor who were actively involved in the construction of the building of the consumers. It was conducted 4 times with the key topics which were preference of the cement brand, influencing factor to make the choice of that cement, their influence in the consumer and about the way of quality confirmation of the cement.

\section{Secondary Data}

The Secondary data were collected from the published/ unpublished documents, literatures, previous research of consumer behaviours, brand and advertisements.

\section{DATA ANALYSIS}

The collected data were analyzed with qualitative as well as quantitative technique. The data collected were entered, classified, tabulated and interpreted accordingly using relative importance factor, mean score and standard deviation. MS- Excel and other computer aided suitable tools are used for the processing, analysis and the presentation of the data collected, and they were logically interpreted with appropriate tables/ charts to find the objectives of the study. Similarly, for the statistical interpretation and analysis, Mean, Standard Deviation, Relative Importance Factor, Rank Correlation and Hypothesis Tess were done which are as follows:

$$
\begin{aligned}
& \text { 1. } \operatorname{Mean}(\mu)=\frac{\text { Sum of all variables }}{\text { Frequency of all variables }} \\
& \text { 2. Standard Deviation }(\sigma)=\sqrt{\frac{\sum(X-X)^{2}}{n-1}}
\end{aligned}
$$

\section{Hypothesis Tests}

Two tailed hypothesis test was done for the descriptive analysis of the influencing factor in the purchasing behaviour of the consumer in which the role of Mason/Contractor, Consultant, Friends and Relatives, Supplier/Retailers and Advertisement were analyzed. Thus, to find the influencer in purchasing decision process, the following hypotheses were framed:

- $\quad$ Null Hypothesis(Ho): Mason/Contractor plays a significant role in purchasing decision process Alternative Hypothesis (H1): Mason/Contractor does not play a significant role in purchasing decision process

- $\quad$ Null Hypothesis(Ho):Supplier/Retailer plays a significant role in purchasing decision process Alternative Hypothesis (H1): Supplier/Retailer does not play significant role in purchasing decision process

- $\quad$ Null Hypothesis(Ho): Consultant plays a significant role in purchasing decision process Alternative Hypothesis (H1): Consultantdoes not play significant role in purchasing decision process

- $\quad$ Null Hypothesis(Ho): Advertisementplays a significant role in purchasing decision process Alternative Hypothesis (H1): Advertisement does not play significant role in purchasing decision process

- $\quad$ Null Hypothesis(Ho): Friend/ Relatives plays a significant role in purchasing decision process Alternative Hypothesis (H1): Friend/ Relatives does not play significant role in purchasing decision process

\section{Summary of Methodology}

To achieve the objective of this research various tools and techniques were used. The table below shows the various tools and techniques that were applied to achieve the different objectives of this research in summary.

Table-Error! No text of specified style in document..1: Summary of Methodology

\begin{tabular}{|l|l|l|l|}
\hline S.No. & \multicolumn{1}{|c|}{ Objectives } & \multicolumn{1}{c|}{ Source of Information } & $\begin{array}{c}\text { Interpretation and } \\
\text { Analysis }\end{array}$ \\
\hline 1 & $\begin{array}{l}\text { To identify the consumer } \\
\text { influencing factor in decision } \\
\text { making to select the cement } \\
\text { brands. }\end{array}$ & $\begin{array}{l}\text { Existing Documents, Reports, Questionnaire } \\
\text { Survey coducted in suppliers and consumers, } \\
\text { interview with key informants and group } \\
\text { discussions with mason and contractor }\end{array}$ & $\begin{array}{l}\text { Analytical facts and } \\
\text { figures, KII and FGD }\end{array}$ \\
\hline
\end{tabular}




\section{Consumer Influencing Factors in Cement Selection}

Consumers were asked about the several determinants with variable to analyze the factors influencng their decision to purchase particular cement brands. Quality, brand image, years of establishment and availability are found to be the major determinants while external environments such as advertisement, consultant, friends and relatives, marketing strategies are the influencing factors in changing the percepetion and cognitive behaviour of the consumers.

\section{Socio-Demographic Characteristics}

During the questionnaire survey, consumers were asked about their socio-demographic status as it plays the vital role in the behavioural perspective in the purchasing decision of the cement brands. Table 4.1below illustrates the major characteristics of consumers involved in the survey:

Table-Error! No text of specified style in document..2: Socio-Demographic Distribution of Consumers

\begin{tabular}{|l|l|l|}
\hline \multicolumn{2}{|c|}{ Socio-Demographic Characteristics } & Percentage of consumers \\
\hline \multirow{4}{*}{ Age } & $18-28$ years & 6.67 \\
\cline { 2 - 3 } & $29-39$ years & 43.33 \\
\cline { 2 - 3 } & $40-50$ years & 40.00 \\
\cline { 2 - 3 } & $51-61$ years & 6.67 \\
\cline { 2 - 3 } & $>61$ years & 3.33 \\
\hline Family Income & $<50$ Thousand & 3.33 \\
\cline { 2 - 3 } & 50 Thousand-1 Lakhs & 43.33 \\
\cline { 2 - 3 } & 1.01 Lakh -3 Lakhs & 26.67 \\
\cline { 2 - 3 } & 3.01 lacs- 5 Lakhs & 13.33 \\
\cline { 2 - 3 } & $>5$ Lakhs & 13.33 \\
\hline Educational Qualification & Undergraduate & 33.33 \\
\cline { 2 - 3 } & Graduate & 33.33 \\
\cline { 2 - 3 } & Post Graduate & 30.00 \\
\cline { 2 - 3 } & Other & 3.33 \\
\hline
\end{tabular}

\section{Factors Considered to Purchase the Specific Cement Brand}

Consumersare influenced by several factors in making decision to purchase the specific cement brand. The perception factors play the decisive role in purchasing cement which depends upon their attitudinal behaviour, quality, brand image, packaging and the price of cement.

During the study, it was found that $70 \%$ of respondents were aware of the quality while $26.67 \%$ considered brand image as the important factor. As outlined in the literature review section 2.4.2, it shows that large group of consumers focus more in the quality of the product which drags them to another level of brand conciousness and therefore its loyalty evolves from the quality that they get from the cement.

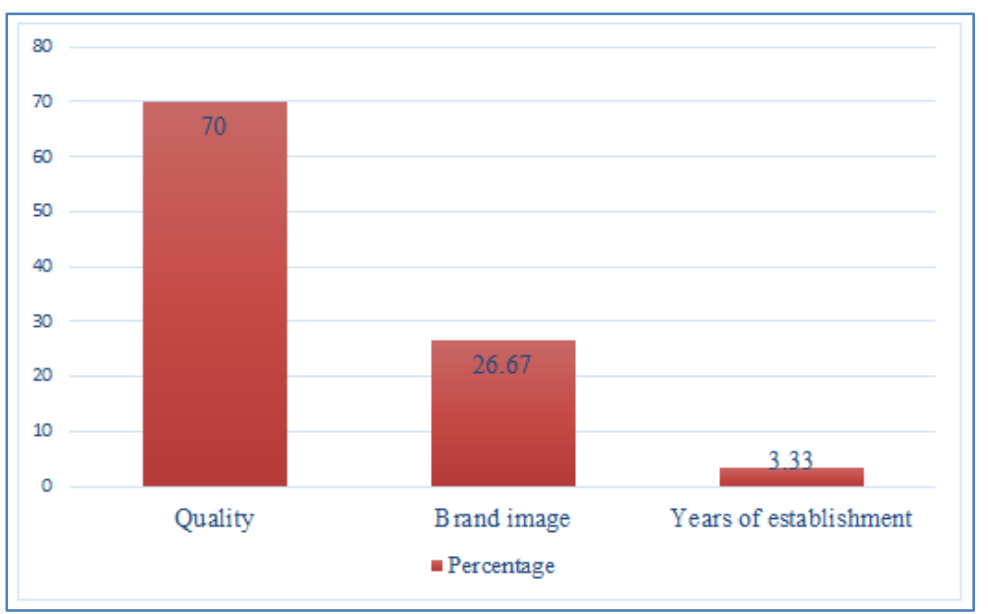

Fig-Error! No text of specified style in document..2: Major factors considered by consumers while selecting cement brands

\section{Brand}

The study found that $50 \%$ of respondents selected Hetauda cement, $23.34 \%$ and $20 \%$ of respondent's selected Udayapur and Shivam cement respectively. It was found that $30 \%$ of the consumer with the age group of 29-39 years have selected Hetauda 
cement while $16.67 \%$ and $3.33 \%$ in the age group of $40-50$ years and $51-61$ years selected that brand. During the KII with the Engineers and Architects, it was known that Hetauda and Udayapur Cement are those brands which have very low frequency of advertisement in the commercial media as compared to other brands. But, these are the brands which carry the brand image as a quality product due its years of establishment and being the government owned company, its demand is increasing through the recommendation of consultants and their friend circle. Also, as discussed in the literature section 2.9.3, the intention to buy Hetauda cement is due to percieved quality.

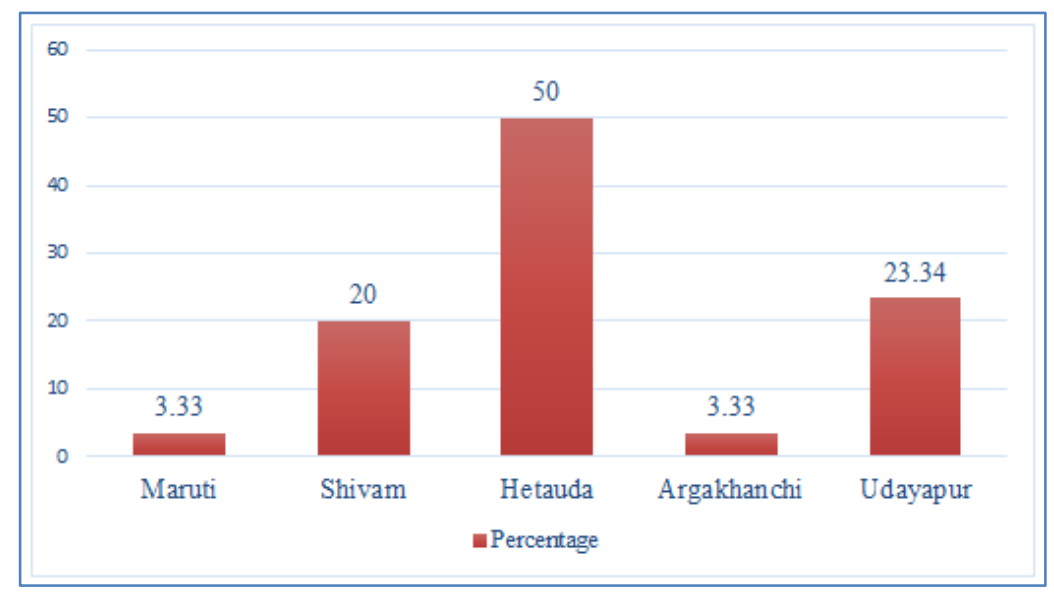

Fig-Error! No text of specified style in document..3: Brand selected by consumers

It is significant that years of establishment has played important role in the selection of cement. As discussed in literature section 2.9, brand is a distinguishable symbol of origin and an assurance of performance which is proved to be right as the consumer choice of cement brand is followed by the years of establishment with the assurance of quality. Table 4.2 shows the years of establishment and price of the cement brands that are selected by the consumer for the construction of their buildings. It is also to be noted that the price has no impact in the selection of the brand as Udayapur and Hetauda cement being the expensive brand incomparison with other brands.

Table-Error! No text of specified style in document..3: Established Year of Cement Brands

\begin{tabular}{|l|l|l|l|}
\hline S/No. & Brand & Established Date & $\begin{array}{l}\text { Price including VAT, Excise duty and } \\
\text { Transportation(NRs.) Per Bag }\end{array}$ \\
\hline 1 & Hetauda & 1976 & 920.00 \\
\hline 2 & Udayapur & 1987 & 950.00 \\
\hline 3 & Maruti Cement & 2007 & 900.00 \\
\hline 4 & Shivam cement & 2009 & 900.00 \\
\hline 5 & Argakhanchi & 2014 & 850.00 \\
\hline
\end{tabular}

\section{Consumer's Medium of Suggestion}

Suggestion and influence by others are two different factors for the consumer. The consumers who take the suggestion from the specific medium may not help to take the decision. It is the process of collecting the recommendation of different cement brands while influence by others takes the consumer to the point of decision. Thus, this study was done to find the medium of suggestion taken by consumer as it has the tendency to get influenced from the same medium from which the consumer takes suggestion.

The study shows that $63.33 \%$ of total respondents take the suggestion from Consultant while $16.67 \%$ chose friends and relatives to consult about the cement. Mason/contractor and Retailer/Supplier are calculated as $10 \%$ and $6.67 \%$ respectively.

Analyzing the age group of the consumers, it was found that $3.33 \%$ of the consumer didn't take the suggestion of any medium to purchase the cement and made their self-decision to purchase the cement while the age group of 40-50 years was found to be dependent with the Consultant as shown in Annexure $\mathrm{C}$. 


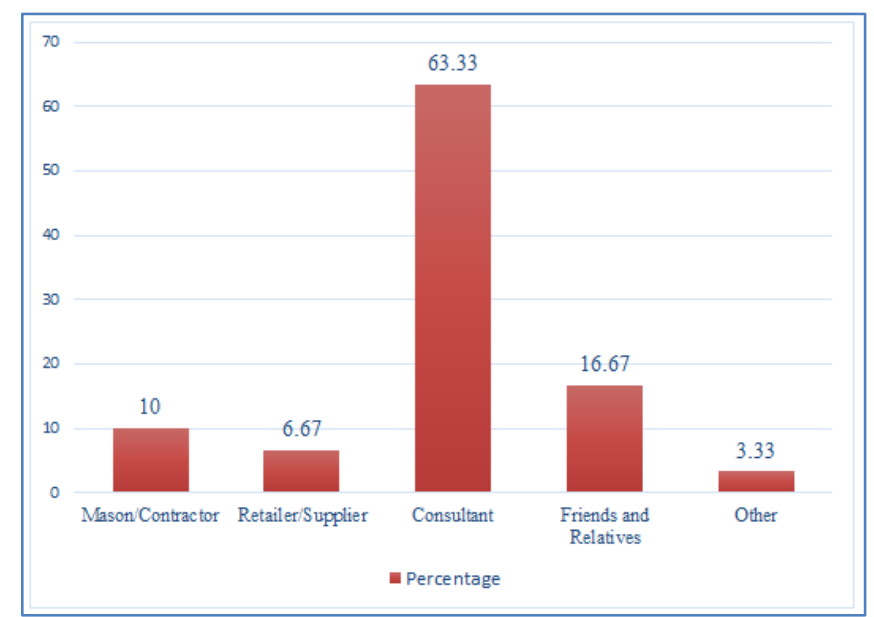

Fig-Error! No text of specified style in document..4: Medium of suggestion taken by consumers in selecting a cement brand

\section{Influential Medium in Making Decision}

To find the influential medium in decision making to purchase the cement, five different determinants were presented to the consumer and are tested with hypothesis mentioned in the section 3.6.

Table 4.3 shows the results of hypothesis tested with four different determinants of influencing medium in decision process to purchase the cement brands. Testing at $5 \%$ level of significance, null hypothesis was rejected for the determinants Mason/Contractor, Supplier/Retailer and Advertisement while it is accepted in the case of Consultant and Friends/Relatives. It means that the Consultant and Friend/Relatives plays a significant role in purchasing decision process of cement brands available in the market while the Mason/Contractor, Supplier/Retailer and Advertisement have nosignificance in the decision process of the consumer.

Table-Error! No text of specified style in document..4: Analysis of influential medium in decision process

\begin{tabular}{|c|c|c|c|c|c|}
\hline Statement of Hypothesis & $\begin{array}{l}\text { Sample } \\
\text { mean }\end{array}$ & $\begin{array}{l}\text { Standard } \\
\text { deviation }(\sigma)\end{array}$ & Z Observed & $\begin{array}{l}Z \text { Critical } \\
\alpha=0.05\end{array}$ & $\begin{array}{l}\text { Null Hypothesis } \\
\text { Status }\end{array}$ \\
\hline $\begin{array}{l}\text { Ho: Mason/Contractor plays a } \\
\text { significant role in purchasing } \\
\text { decision process }\end{array}$ & 2.74 & 1.06 & -3.90 & 1.96 & $\begin{array}{l}\text { Ho Rejected } \\
\text { H1Accepted }\end{array}$ \\
\hline $\begin{array}{l}\text { Ho: Supplier/Retailer plays a } \\
\text { significant role in purchasing } \\
\text { decision process }\end{array}$ & 2.68 & 0.94 & -4.77 & 1.96 & $\begin{array}{l}\text { Ho Rejected } \\
\text { H1Accepted }\end{array}$ \\
\hline $\begin{array}{l}\text { Ho: Consultant plays a } \\
\text { significant role in purchasing } \\
\text { decision process }\end{array}$ & 4.03 & 0.60 & 4.82 & 1.96 & $\begin{array}{l}\text { HoAccepted } \\
\text { H1 Rejected }\end{array}$ \\
\hline $\begin{array}{l}\text { Ho: Advertisement plays a } \\
\text { significant role in purchasing } \\
\text { decision process }\end{array}$ & 2.52 & 0.72 & -7.44 & 1.96 & $\begin{array}{l}\text { Ho Rejected } \\
\text { H1Accepted }\end{array}$ \\
\hline $\begin{array}{l}\text { Ho: Friend/ Relatives plays a } \\
\text { significant role in purchasing } \\
\text { decision process }\end{array}$ & 3.81 & 0.79 & 2.12 & 1.96 & $\begin{array}{l}\text { HoAccepted } \\
\text { H1 Rejected }\end{array}$ \\
\hline
\end{tabular}

The study shows the consumer are influenced by others which involves consultant, friends/relatives as the most influential medium with $50 \%$ and $30 \%$ respectively while mason/contractor, retailer/supplier and self-decision being $10 \%, 6.67 \%$ and $3.33 \%$ respectively as shown in the figure 4.4. As discussed in the literature section 2.8., 'influence by others' factor has played the role of the concumer perception in the brand selection. It is significant that advertisement has not influencing role in making decision to the consumer but it is rather found as the awareness tool for the manufacturer for its brand recognition. 


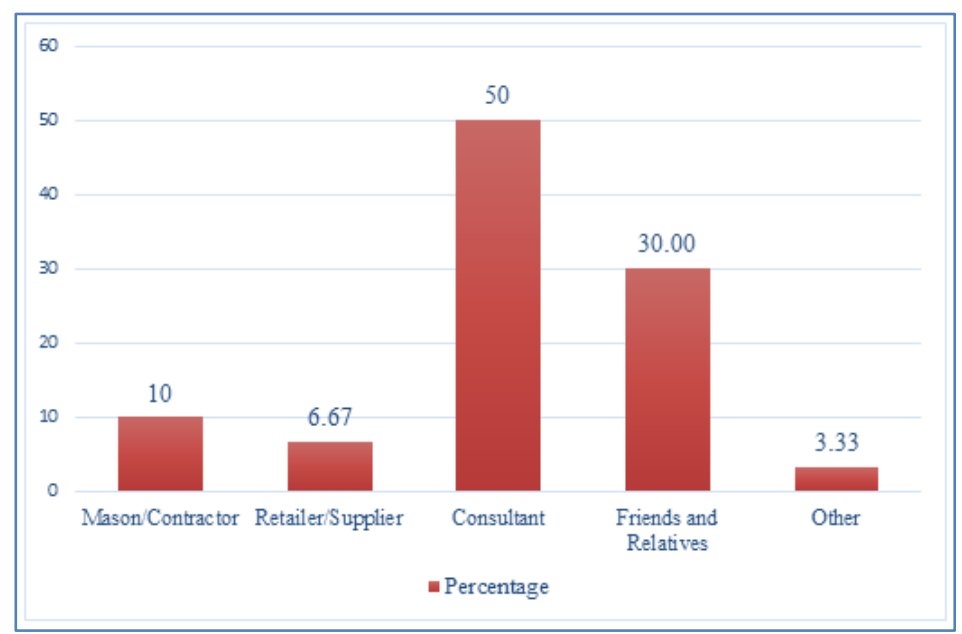

Fig-Error! No text of specified style in document..5: Influential medium in decision process

As discussed in the literature section 2.8 about the brand awareness, advertisement has played the role of positive impression and their existence in the market only as the consumers are not influenced by the advertisement, 'Influence by others'have played important role in consumer's decision processes which was also acknowledged during KII that consumers have the habit of consulting each other regarding a new product or brand and seeking their advice. Purchasing decision also get affected Also, during the interview with the key informants, purchase decision is also affected by attitude of friends which means that when the consumer comes in contact with their friends before the construction and he/she tells the cement of his preference as the best quality cement which forces that consumer to buy that cement though he have another cement brand in mind to purchase. It was also discussed during FGD, where Contractor believes that the consumers are widely influenced by the prior users and the experts of the similar field. The consumer seeks to confirm the quality from the prior users and the experts. Thus, the study shows that advices of other people have a strong effect on consumers buying behaviour.

\section{CONCLUSIONS}

Consumer personality is influenced by risk aversion factor where the consumer seeks to be certain and sure of what they are purchasing. For this, consumer has influence by others characteristics which are consultant, friends and relatives where consultant is considered as the expert and friends/relatives are the prior users of the specific brand. In this way, consumer's decision process is motivated and comes to the point of purchase. Highest consumer choice cement brand is Hetauda cement with $50 \%$ of total consumers followed by Udayapur, Shivam, Maruti and Argakhachi cement which are $23.33 \%, 20 \%, 3.34 \%$ and $3.33 \%$ respectively. Consumers are much focused in the quality and the brand of cement rather than its price as the 2015 earthquake being the major lesson and future threat to the consumer. The medium of quality assurance is found to be consultant, friend and relatives. It is significant that the, years of establishment have played an important role to create the brand image in the consumer to make the decision while purchasing cement, as the highest chosen Hetauda cement is the oldest cement factory amongst other cement brands.

Though, Hetauda cement is perceived as the quality brand by consumer, they are found to be 'Shifting Loyal Consumer'. Consumer is not committed with the brand as Hetauda cement fails to supply the product with respect to the demand. As a result, consumers make the preference for the second brand in terms of quality, brand image and availability being the major determinants while advertisement and promotional tools being the external driver to aware about the brands.

The study also shows that, though Shivam and Maruti cement are established in two years' difference period only, $20 \%$ of the consumer have already used Shivam cement while only 3.34\% have used Maruti cement. Since, Shivam cement is doing aggressive advertisement through different media with sales promotional tool in different level from dealer to the end consumer and the availability of cement to meet the demand have resulted to keep in the high preference cement.

\section{RECOMMENDATIONS}

Hetauda cement manufacturer should increase its production capacity to meet the demand of the consumer during any period of the year which couldpotentially leads to consumer to change into 'Committed Loyal Consumer'. Quality and brand image are the most imporant determinants to choose the cement brands for the construction of the building of consumer. Thus, the manufacturers should confirm the quality of their brand in the effective way which helps to create the brand image in the market. Since, Hetauda cement have inconsistent production throughout the year, other cement manufacturer can use this opportunity by availing the product throughout the year which helps to shift the consumer to those brands. Ultimately, upon the satisfaction and availability of the cement, consumer can be committed loyal consumer of that brand in the future as well as influencing medium of their friends and relatives. 


\section{REFFERENCE}

1. Mishra, A. K., \& Jha, A. (2019). Assessment of Structure of Credit Policy and Sales Trend of Sarbottam Cement. Journal of Advanced Research in Business Law \& Technology Management, 2(1), 14-20.

2. Mishra, A. K., \& Jha, A. (2019). Quality Assessment of Sarbottam Cement of Nepal. International Journal of Operations Management and Services, 9(1), 1-22.

3. Mishra, A. K., \& Chaudhary, E. U. (2018). Cost effectiveness assessment of different nepalese cement brands for selected sites of supermarket. Journal of Advanced Research in Construction \& Urban Architecture, 3(3), 12-33.

4. Mishra, A. K., \& Chaudhary, E. U. (2018). Assessment of cement handling behaviour for selected construction sites of bhatbhateni supermarket. Journal of Advanced Research in Construction \& Urban Architecture, 3(3), 1-11.

5. $\quad$ Engel, J. F., \& Roger, D. (1993). Blackwell and Paul W. Miniard (1995). Consumer behavior, 1.

6. Goffman, E. (1959). The moral career of the mental patient. Psychiatry, 22(2), 123-142.

7. Eysenck, H. J., \& Eysenck, S. B. G. (1975). Manual of the Eysenck Personality Questionnaire (junior and adult). Hodder and Stoughton.

8. Pervin, L. A. (1984). Current controversies and issues in personality. John Wiley \& Sons.

9. Anderson, P. F. (1983). Marketing, scientific progress, and scientific method. Journal of marketing, 47(4), 18-31.

10. Piirto, R., \& Misner, J. (1991). Beyond mind games: The marketing power of psychographics. Ithaca, NY: American Demographics Books.

11. Politz, A. (1958). Motivation Research-Opportunity or Dilemma?. Ferber, R. and Wales, HG, Motivation and Marketing Behaviour, Richard D. Irwin, Inc, 57-58.

12. Holbrook, M. B., \& Hirschman, E. C. (1982). The experiential aspects of consumption: Consumer fantasies, feelings, and fun. Journal of consumer research, 9(2), 132-140.

13. Ajzen, I., \& Fishbein, M. (1977). Attitude-behavior relations: A theoretical analysis and review of empirical research. Psychological bulletin, 84(5), 888.

14. Rosenberg, M. J. (1956). Cognitive structure and attitudinal affect. The Journal of abnormal and social psychology, 53(3), 367.

15. Leigh, J. H., \& Martin, C. R. (1981). A review of situational influence paradigms and research. Review of marketing, 57-74.

16. Feldman, L. P., \& Hornik, J. (1981). The use of time: An integrated conceptual model. Journal of consumer research, 7(4), 407-419.

17. Anderson, P. F. (1986). On method in consumer research: a critical relativist perspective. Journal of consumer Research, 13(2), 155-173.

18. Allen, C. T., \& Madden, T. J. (1985). A closer look at classical conditioning. Journal of consumer research, 12(3), $301-315$.

19. Fuat Firat, A., Dholakia, N., \& Venkatesh, A. (1995). Marketing in a postmodern world. European journal of marketing, 29(1), 40-56.

20. Foxall, G. (1997). Marketing psychology: The paradigm in the wings. Springer.

21. Kotler, P., Wong, V., Saunders, J., \& Armstrong, G. (2005). Principles of Marketing, fourth European edition. Harlow: Pearson Education Limited.

22. Pachauri, M. (2001). Consumer behaviour: a literature review. The Marketing Review, 2(3), 319-355.

23. McDonald, K. L., Sharp, D. J., \& Rickoll, W. (2000). Preparation of thin sections of Drosophila for examination by transmission electron microscopy. Drosophila protocols, 245-271.

24. Kotler, P. (1999). Marketing on Marketing: How to Create, Win and Dominate Markets. Free press.

25. Aaker, D. A. (1996). Building strong brand. New York: Free Press.

26. Kotler, P. (1991). Presentation at the Trustees Meeting of the Marketing Science Institute in November 1990. Boston, MA.

27. Lin, C. C., Liu, W. T., \& Tan, C. S. (2003). Removal of carbon dioxide by absorption in a rotating packed bed. Industrial \& engineering chemistry research, 42(11), 2381-2386.

28. Kotler, P. (2005). Marketing v otázkách a odpovědich. CP books.

29. Kotler, P. (2003). Marketing od A do Z: osmdesát pojmů, které by mněl znát každý manažer. Management Press.

30. Kotler, P. (2000). Marketing Management. The Millennium Education.

31. Doyle, P. (2002). Marketing Management and Strategy, (3rd edition). Harlow: Pearson Education

32. Jones, E., Jones, R., Ebdon, C., Ewen, D., Milner, P., Plunkett, J., \& Jolley, D. (2003). Eocene. The Millennium Atlas: Petroleum Geology of the Central and Northern North Sea. Geological Society, London, 261, 277.

33. Urde, M. (2003). Core value-based corporate brand building. European Journal of marketing, 37(7/8), 1017-1040.

34. Schmit, B. (1999), Experiential Marketing. Accessed from www.doi.org.

35. Kotler, P., \& Armstrong, G. (2004). Marketing. Praha: Grada, 2004. $855 \mathrm{~s}$.

36. Feldwick, P. (2002). What is brand equity, anyway?: selected papers on brands and advertising. World Advertising Research Center.

37. Keller, Kevin, L. (1993). Conceptualizing, Measuring, and Managing Customer-Based Brand Equity. Journal of Marketing.

38. Rossiter, J. R., \& Percy, L. (1987). Advertising and promotion management. McGraw-Hill Book Company.

39. Rossiter, M. J., Williams, T. T., \& Bass, G. A. (1991). Air kerma rate calibration of small sources of 60Co, 137Cs, 226Ra and 192Ir. Physics in medicine \& biology, 36(2), 279.

40. Harvey, D. F., \& Brown, M. F. (1990). Molybdenum carbene complexes: Cyclopropanation of electron-poor 
olefins. Tetrahedron Letters, 31(18), 2529-2532.

41. Gao, X., \& Jiang, L. (2004). Biophysics: water-repellent legs of water striders. Nature, 432(7013), 36.

42. Low, G. S., \& Lamb Jr, C. W. (2000). The measurement and dimensionality of brand associations. Journal of Product \& Brand Management, 9(6), 350-370.

43. Donthu, N., \& Gilliland, D. (1996). Observations: The infomercial shopper. Journal of Advertising Research.

44. Lewis, A., Webley, P., \& Furnam, A. (1995). The New Economic Mind.2nd Ed. Prentice Hall.

45. Kwon, N. S., Nathan, C. F., Gilker, C., Griffith, O. W., Matthews, D. E., \& Stuehr, D. J. (1990). L-citrulline production from Larginine by macrophage nitric oxide synthase. The ureido oxygen derives from dioxygen. Journal of Biological Chemistry, 265(23), 13442-13445.

46. Pitta, D. A., \& Prevel Katsanis, L. (1995). Understanding brand equity for successful brand extension. Journal of consumer marketing, 12(4), 51-64.

47. McDonnell, J., Gatfield, T., Mc Donnell, J., \& Brisbane, N. (1998). SERVQUAL as a cultural change agent in the Australian public sector. In Proceedings of the Australian and New Zealand Marketing Academy Conference (pp. 1528-1539).

48. Szymanski, D. M., \& Henard, D. H. (2001). Customer satisfaction: A meta-analysis of the empirical evidence. Journal of the academy of marketing science, 29(1), 16.

49. Bruner, G.C. (1990). Music, Mood, and Marketing.Journal of Marketing.

50. Parasuraman, A. (1998). Customer service in business-to-business markets: an agenda for research. Journal of business \& industrial marketing, 13(4/5), 309-321.

51. Boulding, E. G., \& Van Alstyne, K. L. (1993). Mechanisms of differential survival and growth of two species of Littorina on wave-exposed and on protected shores. Journal of Experimental Marine Biology and Ecology, 169(2), 139-166.

52. Cronin Jr, J. J., \& Taylor, S. A. (1992). Measuring service quality: a reexamination and extension. Journal of marketing, 56(3), 55-68.

53. Joza, N., Susin, S. A., Daugas, E., Stanford, W. L., Cho, S. K., Li, C. Y., ... \& Ferri, K. F. (2001). Essential role of the mitochondrial apoptosis-inducing factor in programmed cell death. Nature, 410(6828), 549.

54. Taylor, S. A., \& Baker, T. L. (1994). An assessment of the relationship between service quality and customer satisfaction in the formation of consumers' purchase intentions. Journal of retailing, 70(2), 163-178.

55. Oliver, R. L. (1999). Whence consumer loyalty?. Journal of marketing, 63(4_suppl1), 33-44.

56. Odin, G. S., \& Lamaurelle, M. A. (2001). The global Campanian-Maastrichtian stage boundary. Episodes, 24(4), $229-238$.

57. Dekimpe, M. G., Steenkamp, J. B. E., Mellens, M., \& Abeele, P. V. (1997). Decline and variability in brand loyalty. International Journal of Research in Marketing, 14(5), 405-420.

58. Chaudhuri, A., \& Holbrook, M. B. (2001). The chain of effects from brand trust and brand affect to brand performance: the role of brand loyalty. Journal of marketing, 65(2), 81-93.

59. Dolak, D. (2003). Building a Strong Brand: Brands and Branding Basics. Accessed from www.davedolak.com/articles/dolak4.htm

60. Kathmandu-Valley. (2017). Accessed from www.kathmandu-valley-temples.com on June, 2017.

61. Yamane, T. (1967). Statistics, An Introductory Analysis, 2nd Ed.New York: Harper and Row. 